\title{
Brucellosis and bovine tuberculosis in dairy farms in the state of Acre, Brazil
}

\section{Brucelose e tuberculose bovina em fazendas leiteiras no estado do Acre, Brasil}

\author{
Jefferson Viana Alves Diniz ${ }^{\oplus} \odot$, Renato Mesquita Peixoto ${ }^{2 *} \oplus$, Laine Oliveira Silva ${ }^{\circledR}$, \\ Marina Marie Bento Nogueira ${ }^{\circledR}$, Rosano Ramos de Freitas ${ }^{3} \odot$, Rafael Augusto Satrapa ${ }^{3}$
}

\begin{abstract}
This study aimed to evaluate the to evaluate the occurrence rate of bovine brucellosis and tuberculosis in dairy herds of Acre State, Brazil. The survey was performed on 487 lactating cows distributed across 27 farms in seven cities from June 2018 to February 2019. Farms were selected according to the following criteria: volume of milk production (150 L/ day), distance to an urban perimeter $(43 \mathrm{~km})$, and time of dairy activity (12 years). For the diagnosis of brucellosis, buffered acidified plate antigen (BAPA) and complement fixation (CF) tests were used. Among the investigated animals, the occurrence rates for brucellosis and tuberculosis were $1.88 \%(9 / 487)$ and $1.23 \%(6 / 487)$, respectively; among the investigated farms, $11.11 \%(3 / 27)$ and $22.2 \%(6 / 27)$ had livestock diagnosed as positive for brucellosis and tuberculosis, respectively. The farms with tuberculosis-positive cattle possessed some common features with respect to herd size. These farms had considerable herd sizes, which were reared extensively in pastures shared with other susceptible or pathogen-carrying animals. In conclusion, the occurrence rate of bovine brucellosis and tuberculosis in dairy herds from Acre state is, in general, lower than that observed in other states of Brazil. Nevertheless, there is an urgent need for developing strategies to control and eradicate both diseases to prevent eventual outbreaks and pathogen dissemination.
\end{abstract}

KEYWORDS: Brucella sp., epidemiology, Mycobacterium sp., public health, zoonosis

RESUMO: Este estudo teve como objetivo avaliar a taxa de ocorrência de brucelose e tuberculose bovina em rebanhos leiteiros do Estado do Acre, Brasil. A pesquisa foi realizada em 487 vacas em lactação distribuídas em 27 fazendas em sete cidades de junho de 2018 a fevereiro de 2019. As fazendas foram selecionadas de acordo com os seguintes critérios: volume de produção de leite (150 L / dia), distância do perímetro urbano $(43 \mathrm{~km})$, e tempo de atividade leiteira (12 anos). Para o diagnóstico da brucelose, foram utilizados os testes de antígeno acidificado tamponado (AAT) e de fixação de complemento (FC). Entre os animais investigados, as taxas de ocorrência de brucelose e tuberculose foram de 1,88\% (9/487) e 1,23\% (6/487), respectivamente; entre as propriedades investigadas, $11,11 \%(3 / 27)$ e $22,2 \%(6 / 27)$ tiveram rebanhos diagnosticados como positivos para brucelose e tuberculose, respectivamente. As propriedades com rebanho positivo para tuberculose possuíam algumas características comuns com relação ao tamanho do rebanho. Essas fazendas tinham rebanhos consideráveis, que eram criados extensivamente em pastagens compartilhadas com outros animais suscetíveis ou portadores de patógenos. Em conclusão, a taxa de ocorrência de brucelose e tuberculose bovina em rebanhos leiteiros do estado do Acre é, em geral, inferior à observada em outros estados do Brasil. No entanto, há uma necessidade urgente de desenvolver estratégias para controlar e erradicar ambas as enfermidades, para prevenir eventuais surtos e disseminação de patógenos.

PALAVRAS-CHAVE: Brucella sp., epidemiologia, Mycobacterium sp., saúde pública, zoonose

\section{INTRODUCTION}

The responsibility of animal production of countries is mainly attributed to production systems, which lay special emphasis on maintaining the quality and trustworthiness of the products. In 2001, the Ministry of Agriculture, Livestock and
Supply launched the National Program for the Control and Eradication of Brucellosis and Tuberculosis (PNCEBT), which was recently revised through the Normative Instruction (IN) number 10 of March 03, 2017. This program considers that livestock diseases cause great economic and social losses due

${ }^{1}$ Campus Sena Madureira, Instituto Federal do Acre, Sena Madureira, Acre, Brasil

2Bolsista de Desenvolvimento Científico e Tecnológico Regional do Conselho Nacional de Desenvolvimento Científico e Tecnológico (DCTR - CNPq/FUNCAP), nível C, na Embrapa Caprinos e Ovinos (CNPCO), Sobral, Ceará, Brasil

${ }^{3}$ Programa de Pós-Graduação em Sanidade e Produção Animal Sustentável na Amazônia, Universidade Federal do Acre, Rio Branco, Acre, Brasil

*Corresponding author: renatomiraima@gmail.com

Received: 08/04/2020. Accepted: 12/16/2020 
to their negative impact on the productivity of flocks and concomitant risks to human health (BRASIL, 2006).

Brucellosis and tuberculosis are zoonosis caused by bacteria of the genera Brucella and Mycobacterium, respectively (BRAZIL, 2006). While brucellosis causes clinical symptoms such as abortions, premature births, and infertility, which reduce milk production (SANTOS et al., 2013), tuberculosis is characterized by the occurrence of nodular lesions in different organs and tissues. The latter disease affects mostly cattle and buffaloes, which may transmit to humans, thus causing nationwide socio-economic distress (GOODCHILD; CLIFTON-HADLEY, 2001).

Hence, the epidemiological investigation of brucellosis and tuberculosis is essential to verify the efficacy of national programs for control and eradication of these diseases. There are only a few studies that have assessed the epidemiology of livestock diseases in the western Amazon region, where the Acre State is located. Therefore, this study aimed to assess the occurrence rate of bovine brucellosis and tuberculosis in the dairy flocks of Acre, Brazil.

\section{MATERIALS AND METHODS}

This study was approved by the Ethics Committee for the Use of Animals of the Federal Institute of Education, Science and Technology from Acre (protocol number 03/2017). The survey was performed on 27 farms distributed across seven cities in Acre. A total of 487 native, mixed-breed lactating cows (Bos taurus taurus $\mathrm{x}$ Bos taurus indicus), uni or multiparous, aged 3-6 years, were tested. Animals were reared extensively with free access to water and mineral salt, and their body condition scores ranged from 3 to 4 on a scale of 1 to 5 . The investigation was conducted from June 2018 to February 2019. Farms were selected based on the following criteria: volume of milk production ( $150 \mathrm{~L} /$ day), distance to an urban perimeter $(43 \mathrm{~km})$, and time of dairy activity (12 years) (Figure 1).

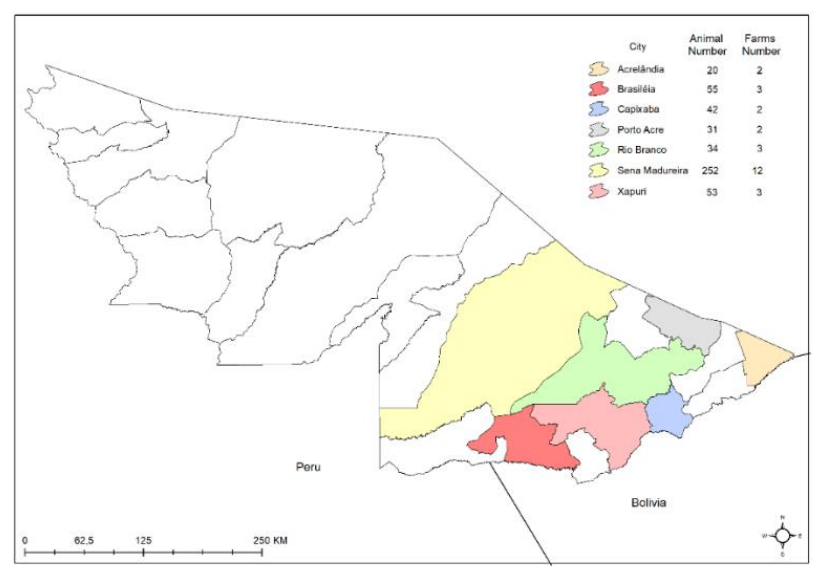

Figure 1. The map of the cities included in the study to detect animals positive for brucellosis and tuberculosis in the state of Acre, Brazil.
For the diagnosis of brucellosis, a blood sample from each animal was collected through venipuncture of the coccygeal vein in vacuum tubes without anticoagulant and with separating gel. After sampling, the tubes were kept tilted at room temperature for $10 \mathrm{~min}$, followed by centrifugation at $900 \mathrm{~g}$ for $10 \mathrm{~min}$.

Serum samples were tested using the buffered acidified plate antigen (BAPA) test. The result was determined after four minutes of homogenization (serum + BAPA), where the absence or presence of agglutinates was interpreted as brucellosis negative or positive, respectively. Samples that tested positive by the BAPA test were then further examined using the complement fixation (CF) technique, in which complement proteins bind to antigen-antibody complexes and result in hemagglutination, according to the method described in the PNCEBT manual using a minimum titer reference value of $\geq 20$ IU (BRASIL, 2006).

For the diagnosis of tuberculosis, animals were identified with numbered earrings, and a trichotomy area of $3 \mathrm{~cm}^{2}$ (on average) was prepared in the scapular region. Then, an analogical cutimeter was used to measure the thickness of the skin fold in the shaved area, and the values were recorded. Following skin asepsis with 70\% alcohol, a pistol type syringe was used to intradermally inject $0.1 \mathrm{~mL}$ of bovine tuberculine pure protein derivative (PPD), comprising purified protein derivatives of $M$. bovis strain AN5 $(1 \mathrm{mg} / \mathrm{mL}, 32.500 \mathrm{IU} / \mathrm{mL})$ and avian protein from M. avium strain D4 ER $(0.5 \mathrm{mg} / \mathrm{mL}$, $25.000 \mathrm{IU} / \mathrm{mL}$ ), purchased from VAC-SULES. Avian PPD was inoculated cranially as control. After $72 \mathrm{~h}$, the thickness of the skin fold was measured and recorded again. The increase in thickness was calculated and interpreted according to the criteria established by the PNCEBT (BRASIL, 2006).

Data obtained from the tests were analyzed using the software R Core Team version 3.2.1 for Windows. Statistical tests with a significance level of $5 \%$ were used.

\section{RESULTS}

Data analysis revealed that $2.63 \%$ (13/487) and 1.88\% (9/487) of cows tested positive for brucellosis in the BAPA test and CF test, respectively. Furthermore, 1.23\% (6/487) were diagnosed as tuberculosis-positive (Table 1).

Table 1. Bovine brucellosis and tuberculosis in dairy flocks from Acre State, Brazil.

\begin{tabular}{l|c|c|c|c|c|c}
\multirow{2}{*}{ Parameter } & \multicolumn{4}{|c|}{$\begin{array}{c}\text { Bovine } \\
\text { brucellosis }\end{array}$} & \multicolumn{2}{c}{$\begin{array}{c}\text { Bovine } \\
\text { tuberculosis }\end{array}$} \\
\cline { 2 - 7 } & \multicolumn{2}{|c|}{ BAPA } & \multicolumn{2}{c}{ CF } & \multicolumn{2}{c}{ CCT } \\
\cline { 2 - 7 } & $\mathrm{N}$ & $\%$ & $\mathrm{~N}$ & $\%$ & $\mathrm{~N}$ & $\%$ \\
\hline Positive & 13 & 2.67 & 9 & 1.85 & 6 & 1.23 \\
\hline Negative & 474 & 97.33 & 478 & 98.15 & 481 & 98.77 \\
\hline Total & 487 & 100 & 487 & 100 & 487 & 100 \\
\hline
\end{tabular}

BAPA = Buffered Acidified Plate Antigen; $\mathrm{CF}=$ Complement Fixation; $\mathrm{CCT}=$ Comparative Cervical Test; $\mathrm{N}=$ Number of samples; $\%$ = Percentage. 
Among the 27 investigated farms, 11.11\% (3/27) and $3.7 \%(1 / 27)$ were found to have brucellosis-positive animals in the BAPA and CF tests, respectively. Tuberculosis-positive animals were identified in $22.22 \%(6 / 27)$ of farms (Table 2).

The $69.23 \%$ (9/13) of animals that were brucellosispositive by the BAPA test also tested positive by the CF test. Hence, the screening test (BAPA) showed sufficient efficiency to be considered for use as a routine test, considering that only $30.76 \%$ (4/13) of animals diagnosed as brucellosis-positive in this test tested negative using the confirmatory exam (CF).

Among the three farms that had brucellosis-infected animals according to the BAPA and/or CF tests, one also contained tuberculosis-infected animals. This farm was found to engage in livestock trade more frequently than the others, and this increased trade activity may be associated with an increased risk of pathogen entry. Furthermore, this farm was also the least technologically advanced among all the investigated farms, with respect to ectoparasite and endoparasite control, management, and pasture division.

The farms that had tuberculosis-positive animals possessed considerably large herds, which were reared extensively using pastures shared with other potentially susceptible or pathogencarrying animals. In addition, these farms acquired breeders from areas of elevated epidemiological risk and showed poor adherence to the requirements for quarantine or mandatory diagnostic tests.

\section{DISCUSSION}

The bovine brucellosis data obtained in this study shows a lower rate of disease occurrence in Acre compared with the average $4.1 \%$ found in North Brazil (POESTER GONÇALVES; LAGE, 2002). In addition, the rate of brucellosis occurrence in Acre was also lower than that reported in other states of this region, such as Amazonas, Pará, and Tocantins, which presented seroprevalence levels of $6.42 \%, 16.6 \%$, and $17.2 \%$, respectively (FERREIRA; RIBEIRO; FRANCENER, 2018; VIANA et al., 2010). However, brucellosis occurrence rate reported in this study was similar to that in the state of Santa Catarina $(0.91 \%)$, which had the lowest national occurrence rate for bovine brucellosis. Santa Catarina successfully controlled the

Table 2. Occurrence rates of bovine brucellosis and tuberculosis in dairy farms of Acre State, Brazil.

\begin{tabular}{l|c|c|c|c|c|c}
\multirow{2}{*}{ Parameter } & \multicolumn{4}{c|}{$\begin{array}{c}\text { Bovine } \\
\text { brucellosis }\end{array}$} & \multicolumn{2}{c}{$\begin{array}{c}\text { Bovine } \\
\text { tuberculosis }\end{array}$} \\
\cline { 2 - 8 } & \multicolumn{2}{|c|}{ BAPA } & \multicolumn{2}{c}{ CF } & \multicolumn{2}{c}{ CCT } \\
\cline { 2 - 7 } & N & $\%$ & N & $\%$ & N & $\%$ \\
\hline Positive & 3 & 11.11 & 1 & 3.70 & 6 & 22.22 \\
\hline Negative & 24 & 88.89 & 26 & 96.30 & 21 & 77.78 \\
\hline Total & 27 & 100 & 27 & 100 & 27 & 100
\end{tabular}

BAPA = Buffered Acidified Plate Antigen; $C F=$ Complement Fixation; $C C T$ $=$ Comparative Cervical Test; $\mathrm{N}=$ Number of samples; $\%=$ Percentage. disease by the implementation of strategies mostly based on routine diagnostic testing and timely elimination of brucellosis-positive animals (BAUMGARTEN et al., 2016).

The high occurrence rate of brucellosis is linked to low rates of vaccination, and despite the mandatory immunization policy, most Brazilian herds do not have a vaccination coverage of $100 \%$ (ALVES et al., 2015). Vaccination of cows until 8 months of age is an efficient approach to lower brucellosis occurrence rates, and this measure has been demonstrated to significantly reduce disease occurrence in the state of Mato Grosso (BARDDAL et al., 2002).

The losses caused by brucellosis are linked to animal reproduction. In one of the few studies performed in the state of Acre, a $2.89 \%$ rate of brucellosis occurrence was determined in cows subjected to fixed-time embryo transfer. In addition, the negative influence of $\mathrm{B}$. abortus infection on pregnancy and abortion rates led to great economic losses in the production systems (DINIZ et al., 2016).

Importantly, the titer of the sample may interfere with the result of the test. Therefore, a combination of distinct serological techniques is recommended for reliable diagnosis (MEIRELLES-BARTOLI; MATHIAS, 2010).

Furthermore, in the current study, two of the farms with brucellosis-positive animals lay in a region bordering Bolivia, while a third farm witnessed heavy traffic of animals, primarily due to a high number of animal movement permits. These factors elevate the risk of disease occurrence. One of the risk factors for the introduction of brucellosis in herds is the acquisition of breeders directly from other farms without mandatory diagnostic tests, a common practice among farmers in several regions of Brazil (MOTA et al., 2016). This practice facilitates the dissemination of brucellosis across farms and cities. In addition, the average livestock production system of small farms is of special concern in this regard, because farmers usually lack adequate knowledge of the risks associated with this disease.

Concerning public health, brucellosis greatly impacts the human population, mainly in rural areas where the exposure to the pathogen is greater. Increased human exposure to brucellosis is a consequence of a high rate of infection in livestock. In fact, there are reports of $21 \%$ occurrence rates in family nuclei where at least one individual tested positive in the serological test for brucellosis (HOMEM et al., 2016). In the same study, a $52 \%$ rate of occurrence of bovine brucellosis was also observed. This implies that the human population in these rural regions with high occurrence rates of bovine brucellosis are at a risk of high pathogen exposure, even if notifications of the disease in humans are rare owing to the non-specific clinical symptoms of the infection.

The occurrence rate of livestock tuberculosis in Acre observed in the current study was $1.23 \%$. This rate is consistent with the rate of infection (2.3\%) reported in the state of Rondônia (VENDRAME et al., 2016). The higher disease 
occurrence rate in dairy cattle herds may be attributed to farm characteristics, specific management strategies for this type of production, and greater average lifespan of the breeders (VENDRAME et al., 2016). Greater number of tuberculosis outbreaks in regions with a predominance of dairy farms have also been observed, for instance in the state of Pernambuco (LIMA et al., 2016). It is likely that the rate of disease dissemination is dependent on the population density of herds resulting from dairy intensification. Hence, areas with elevated concentrations of dairy farms have greater potential of disease dissemination (GOODCHILD; CLIFTON-HADLEY, 2001).

A study performed in the states of Minas Gerais and Rondônia indicated that dairy production-associated technological advancement is the main risk factor for disease occurrence; for instance, total or partial animal confinement has been linked to a high probability of infection (VIANA et al., 2010; BELCHIOR et al., 2016). In contrast, dairy cattle production in Acre State is predominantly performed in extensive systems, which dampens disease dissemination.

Tuberculosis causes great economic losses, mostly due to animal loss. A study conducted in the city of Garanhuns in the state of Pernambuco reported a high occurrence rate of tuberculosis in cattle slaughtered in an abattoir (SILVA et al., 2018). This observation underscores the need to improve control programs that monitor such establishments, particularly considering the consequences of the disease with respect to public health.

Currently, brucellosis and tuberculosis both occur in dairy farms nationwide, causing great losses to farmers and posing a potential risk to population health. Even with the implementation of PNCEBT almost two decades ago, the occurrence rates of these diseases are still worryingly high, with more severe implications for smallholder farmers. Hence, public policies should be intensified to improve epidemiological surveillance and develop educational programs for farmers.

\section{CONCLUSION}

The occurrence rates of bovine brucellosis and tuberculosis in dairy herds from Acre State are, in general, lower than those reported in other states of Brazil. Nevertheless, there is a pressing need for strategies to control and eradicate both diseases to prevent future outbreaks and pathogen dissemination.

\section{ACKNOWLEDGEMENTS}

Instituto Federal de Educação, Ciência e Tecnologia do Acre; Universidade Federal do Acre (EDITAL PROPEG No 14/2020); Conselho Nacional de Desenvolvimento Científico e Tecnológico (CNPq) and Fundação Cearense de Apoio ao Desenvolvimento Científico e Tecnológico for the scholarships of R.M. Peixoto.

\section{REFERENCES}

ALVES, A. J. S. et al. Economic analysis of vaccination to control bovine brucellosis in the States of São Paulo and Mato Grosso, Brazil. Preventive Veterinary Medicine, v.118, n.4, p.35l-358, 2015.

BARDDAL, J. E. I. et al. Effect of vaccination in lowering the prevalence of bovine brucellosis in the state of Mato Grosso, Brazil. Semina: Ciências Agrárias, v.37, n.5, p.3479-3492, 2016.

BAUMGARTEN, K. D. et al. Prevalence and risk factors for bovine brucellosis in Santa Catarina state, Brazil. Semina: Ciências Agrárias, v.37, n.5, p.3425-3436, 2016.

BELCHIOR, A. P. C. et al. Prevalence and risk factors for bovine tuberculosis in Minas Gerais State, Brazil. Tropical Animal Health and Production, v.48, n.3, p.373-78, 2016.

BRASIL. Ministério da Agricultura Pecuária e Abastecimento. PNCEBT, 2006, 184p. Disponível em: <www.agricultura.gov.br/ assuntos/sanidade-animal-e-vegetal/saude animal/programas-desaude-animal/controle-e-erradicacao-da-brucelose-e-tuberculosepncebt>. Acesso em: 11 nov. 2018.

MEIRELLES-BARTOLI, R. B.; MATHIAS, L. A. 2010. Estudo comparativo entre os testes adotados pelo PNCEBT para o diagnóstico sorológico da brucelose em bovino. Arquivos do Instituto Biológico, v.77, n.l, p.11-17, 2010.
DINIZ, J. V. A. et al. Immune-serological identification of infectious agents with influence on bovine embryo transfer in the north of Brazil. Archivos de MedicinaVeterinaria, v.48, n.2, p.145-152, 2016.

FERREIRA, J.C.C.; RIBEIRO, T.M. P.; FRANCENER, S. F.Soroprevalência da brucelose em bovinos abatidos sob fiscalização estadual em Itacoatiara, Amazonas. Revista Brasileira de Higiene e Sanidade Animal, v.12, n.4, p.477-486, 2018.

GOODCHILD, A. V.; CLIFTON-HADLEY, R. S. Cattle-to-cattle transmission of Mycobacterium bovis. Tuberculosis, v.81, n.l-2, p.23-4l, 2001.

HOMEM, V. S. F. et al. Bovine and human brucellosis in the TransAmazonian agricultural frontier, Uruará, Pará, Brazil. Semina: Ciências Agrárias, v.37, n.5, p.3803-3808, 2016.

LIMA, P. R. B. et al. Epidemiological situation of bovine tuberculosis in the state of Pernambuco, Brazil. Semina: Ciências Agrárias, v.37, n.5, p.3601-3610, 2016.

MOTA, A. L. A. A et al. Large-scale study of herdlevel risk factors for bovine brucellosis in Brazil. Acta Tropica, v.164, p.226-232, 2016.

POESTER, F. P.; GONÇALVES, V. S. P.; LAGE, A. P. Brucellosis in Brazil. Veterinary Microbiology, v.90, n.l-4, p.55-62, 2002. 
SANTOS, R. L. et al. Economic losses due to brucellosis in Brazil. Pesquisa Veterinária Brasileira, v.33, n.6, p.759-764, 2013.

SILVA, S. C. G. et al. Isolation and identification of Mycobacterium bovis in cattle slaughtered from an abattoir in Garanhuns, Pernambuco. Semina: Ciências Agrárias, v.39, n.l, p.157166, 2018.
VENDRAME, F. B. et al. Epidemiologic characterization of bovine tuberculosis in the State of Rondônia, Brazil. Semina: Ciências Agrárias, v.37, n.5, p.3639-3646, 2016.

VIANA, L. et al. Soropositividade e lesões sugestivas de brucelose em bovinos abatidos no estado de Tocantins, Brasil. Arquivos do Instituto Biológico, v.77, n.3, p.517-520, 2010. 